\title{
The role of proteolysis in T cell apoptosis triggered by chelation of intracellular $\mathrm{Zn}^{2+}$
}

\author{
Shunai Jiang ${ }^{1}$, Boris Zhivotovsky ${ }^{1}$, David H. Burgess ${ }^{1}$, \\ Annie Gahm ${ }^{1}$, Sek C. Chow ${ }^{1}$ and Sten Orrenius ${ }^{2}$ \\ 1 Institute of Environmental Medicine, Division of Toxicology, Karolinska \\ Institutet, Box 210, S-171 77 Stockholm, Sweden. \\ tel: +46 8 335874; fax: +46 8 329041; e-mail: Sten.Orrenius@imm.ki.se \\ 2 corresponding author: Institute of Environmental Medicine, Division of \\ Toxicology, Karolinska Institutet, Box 210, S-171 77 Stockholm, Sweden. \\ tel: +46 8 335874; fax: +46 8 329041; e-mail: Sten.Orrenius@imm.ki.se
}

Received 27.5.96; accepted 13.6.96

Edited by G. Melino

\begin{abstract}
Our previous work showed that chelation of intracellular $\mathrm{Zn}^{2+}$ with $\mathrm{N}, \mathrm{N}, \mathrm{N}^{\prime}, \mathrm{N}^{\prime}$-tetrakis (2-pyridylmethyl) ethylenediamine (TPEN) induces apoptosis in rat thymocytes. The molecular mechanism involved in TPEN-triggered apoptosis remains unknown, except that it is a $\mathrm{Ca}^{2+}$-independent process. In the present study, we show that TPEN is unable to induce DNA fragmentation when added to isolated thymocyte nuclei, indicating that activation of a cytoplasmic component is essential for TPEN-induced apoptosis. Since cytosolic proteases related to interleukin-1 $\beta$-converting enzyme (ICE) are implicated as key activators of apoptosis in many different systems, we investigated the possible involvement of such proteases in TPEN-induced apoptosis. We found that treatment of thymocytes with TPEN caused an early degradation of nuclear poly(ADP-ribose) polymerase (PARP) and lamin prior to DNA cleavage. This could be inhibited by ZVal-Ala-Asp-chloromethylketone (VADcmk), an inhibitor of ICE-like proteases, but not by an inhibitor of $\mathrm{Ca}^{2+}$-regulated serine protease. Jurkat $T$ cells also underwent extensive DNA fragmentation when incubated with TPEN. A cytosolic fraction, prepared from TPEN-treated Jurkat cells, produced extensive DNA fragmentation when applied to isolated thymocyte nuclei, whereas the cytoplasmic extract from untreated cells was ineffective either alone or together with TPEN. The apoptosis-inducing activity in cytosolic fraction from TPEN-treated Jurkat cells was blocked by incubating cells in the presence of VADcmk or another inhibitor of ICE-like proteases, Ac-Asp-Glu-Val-Asp-aldehyde (DEVD-CHO), which has been found to competitively inhibit CPP32/apopain. An increase in enzyme activity that cleaves Ac-Asp-Glu-ValAsp-7-amino-4-methylcoumarin (DEVD-AMC), a fluorogenic substrate of CPP32/apopain and $\operatorname{Mch} 3 \alpha$, was detected in TPEN-treated thymocytes and Jurkat cells. In addition, the proteolytic cleavage of CPP32 resulting in the formation of two active fragments (p17 and p12) was observed in cytosolic extracts from TPEN-treated Jurkat cells, but not in extracts which were prepared from cells treated with TPEN in the
\end{abstract}

presence of VADcmk or DEVD-CHO. Our results suggest that activation of cytosolic ICE-like proteases is an essential step in TPEN-induced apoptosis, and that CPP32/apopain is critically involved in this process.

Keywords: thymocytes, Jurkat T cells, TPEN, Zinc, ICE-like proteases, CPP32/apopain

Abbreviations: TPEN, N,N,N',N'-tetrakis (2-pyridylmethyl) ethylenediamine; FBS, fetal bovine serum; VADcmk, Z-ValAla-Asp-chloromethylketone; AAPFcmk, Suc-Ala-Ala-ProPhe-chloromethylketone; ICE, interleukin-1 $\beta$-converting enzyme; HMW, high molecular weight; DEVD-CHO, Ac-Asp-GluVal-Asp-aldehyde; DEVD-AMC, Ac-Asp-Glu-Val-Asp-7-amino-4-methylcoumarin; and PARP, poly(ADP-ribose) polymerase; FIGE, field inversion gel electrophoresis

\section{Introduction}

Cell death by apoptosis has become recognized as a common feature of many biological processes where cell deletion is a mechanism for altering tissue structure and function (Wyllie et al, 1980). Although extensive studies have been carried out to explore the mechanisms involved in this process, a common signaling pathway has not yet been found. It is becoming apparent that virtually every cell has a death program that can be triggered by external stimuli, and that the pathways by which apoptosis is triggered may vary from cell type to cell type and from inducer to inducer (McConkey and Orrenius, 1994). However, the appearance of volume shrinkage, plasma membrane blebbing, chromatin condensation, and DNA fragmentation in most cells undergoing apoptosis suggests that a final common program is involved in the execution of apoptosis (Wyllie et al, 1980; Arends et al, 1991).

Intracellular proteolysis has long been considered to be an important mechanism in the regulation of the levels of individual proteins, as well as overall growth and atrophy of tissues. Recent studies have shown that activation of intracellular proteases also plays a central role in triggering apoptosis (Martin and Green, 1995). Among the many proteases involved in apoptosis, much interest has been given to interleukin-1 $\beta$-converting enzyme (ICE)like proteases. ICE-like proteases are a family of cytoplasmic cysteine proteases which include ICE (Yuan et al, 1993; Miura et al, 1993), CED-3 (Yuan et al, 1993; Miura et al, 1993), NEDD-2/ICH-1 (Kumar et al, 1994; Wang et al, 1994), CPP32/YAMA/apopain (FernandesAlnemri et al, 1994; Tewari et al, 1995b; Nicholson et al, 1995), TX/ICH-2 (Faucheu et al, 1995; Kamens et al, 1995), Mch-2 (Fernandes-Alnemri et al, 1995a), and Mch-3 (Fernandes-Alnemri et al, 1995b). Overexpression of any one of these leads to apoptotic cell death, whereas 
blocking their activity with the specific viral inhibitor, $\operatorname{CrmA}$, or with non-hydrolyzable peptide substrates protects cells from apoptosis.

Thus, the involvement of ICE-like proteases in apoptosis induced by diverse stimuli is now well established (Kumar, 1995). Some of the substrates for ICE-like proteases in apoptosis have been identified, these include poly(ADPribose) polymerase (PARP) (Kaufmann et al, 1993; Lazebnik et al, 1994; Fernandes-Alnemri et al, 1995b; Gu et al, 1995), sterol regulatory element-binding proteins (Wang et al, 1995), the $70 \mathrm{kDa}$ protein component of the U1 small nuclear ribonucleoprotein (Tewari et al, 1995a), and a component of microfilament system, Gas2 (Brancolini et al, 1995). Cleavage of nuclear lamins is another proteolytic event commonly observed in cells undergoing apoptosis (Oberhammer et al, 1994; Neamati et al, 1995; Lazebnik et al, 1995). The proteases responsible for the degradation of nuclear lamins during apoptosis are not fully identified. A $\mathrm{Ca}^{2+}$-regulated serine protease has been found to be responsible for the lamin degradation in the nuclear scaffold extract (Clawson et al, 1992). Recently, Lazebnik et al (1995) also reported that lamin cleavage during apoptosis requires the action of a second ICE-like protease which exhibits kinetics of cleavage and a profile of sensitivity to specific inhibitors that is distinct from PARPcleaving CPP32/YAMA.

$\mathrm{Zn}^{2+}$ is a universal inhibitor of apoptosis (Sunderman, 1995). However, the sites and the mode of inhibition of apoptosis by $\mathrm{Zn}^{2+}$ are still not clear. An early study by Cohen and Duke (1984) showed that $\mathrm{Zn}^{2+}$ inhibits the $\mathrm{Ca}^{2+} /$ $\mathrm{Mg}^{2+}$-dependent endonuclease, which is intrinsically present in thymocyte nuclei and thought to be responsible for the internucleosomal DNA fragmentation induced by glucocorticoids. It was initially assumed that the inhibitory effects of $\mathrm{Zn}^{2+}$ on apoptosis were due to the inhibition of $\mathrm{Ca}^{2+} / \mathrm{Mg}^{2+}$-dependent endonuclease. However, it was later found that $\mathrm{Zn}^{2+}$ also inhibits $\mathrm{Ca}^{2+}$-independent forms of apoptosis (Lazebnik et al, 1993). Thus, inhibition of $\mathrm{Ca}^{2+} /$ $\mathrm{Mg}^{2+}$-dependent endonuclease activity alone is not sufficient to explain the effects of $\mathrm{Zn}^{2+}$ on apoptosis.

In a previous study, we demonstrated that chelation of intracellular $\mathrm{Zn}^{2+}$ with $\mathrm{N}, \mathrm{N}, \mathrm{N}^{\prime}, \mathrm{N}^{\prime}$-tetrakis (2-pyridylmethyl) ethylenediamine (TPEN) is sufficient to induce apoptosis in thymocytes (McCabe et al, 1993). Although the pathway whereby TPEN triggers apoptosis in these cells is unknown, it does not require protein synthesis (McCabe et al, 1993) and is $\mathrm{Ca}^{2+}$-independent (Jiang et al, 1995). In our present study, the mechanisms involved in TPENinduced thymocyte apoptosis have been investigated further. We report that the induction of apoptosis by TPEN is not due to direct effects on the nucleus. Instead, the activation of cytosolic components, including ICE-like proteases, is essential for TPEN-triggered apoptosis.

\section{Results}

\section{Lack of effects of TPEN on thymocyte nuclei}

Since $\mathrm{Zn}^{2+}$ inhibits endonuclease activity (Cohen and Duke, 1984) and stabilizes chromatin structure (Crompton et al,
1992), it appears possible that chelation of $\mathrm{Zn}^{2+}$ by TPEN could induce DNA fragmentation by either de-repressing endonuclease activity or destabilizing chromatin structure. To examine this, the direct effects of TPEN on isolated thymocyte nuclei were investigated. Isolated rat thymocyte nuclei were incubated with $10 \mu \mathrm{M}$ TPEN for $2 \mathrm{~h}$ prior to quantitation of DNA cleavage. $\mathrm{Ca}^{2+}$, which has previously been shown to induce extensive DNA fragmentation in isolated thymocyte nuclei, was used as a positive control. As shown in Figure 1, while $\mathrm{Ca}^{2+}$ resulted in a dose-dependent increase in DNA fragmentation, TPEN failed to induce DNA fragmentation in isolated thymocyte nuclei. Moreover, TPEN had no additional effect on $\mathrm{Ca}^{2+}$-induced DNA fragmentation in thymocyte nuclei. Similar results were obtained with prolonged incubation times (data not shown). Thus, although the addition of $\mathrm{Zn}^{2+}$ inhibits $\mathrm{Ca}^{2+}$-induced DNA fragmentation (Cohen and Duke, 1984), the chelation of $\mathrm{Zn}^{2+}$ by TPEN did not enhance $\mathrm{Ca}^{2+}$-induced DNA fragmentation in isolated nuclei. This result is in agreement with our previous finding that TPENinduced thymocyte apoptosis is $\mathrm{Ca}^{2+}$-independent (Jiang et al, 1995). Together, these findings suggest that the hypothesis is not true, that TPEN induces chromatin fragmentation by either removing endogenous $\mathrm{Zn}^{2+}$ inhibition from $\mathrm{Ca}^{2+} / \mathrm{Mg}^{2+}$-dependent endonuclease(s) or changing chromatin conformation and thereby increasing its susceptibility to cleavage by $\mathrm{Ca}^{2+} / \mathrm{Mg}^{2+}$-dependent endonuclease(s). An alternative hypothesis, namely that TPEN treatment activates a cytosolic apoptosis-promoting activity, was therefore investigated.

\section{Involvement of ICE-like proteases in TPEN-induced thymocyte apoptosis}

Among the possible cytosolic factors which could trigger apoptosis in TPEN-treated thymocytes are the ICE-like

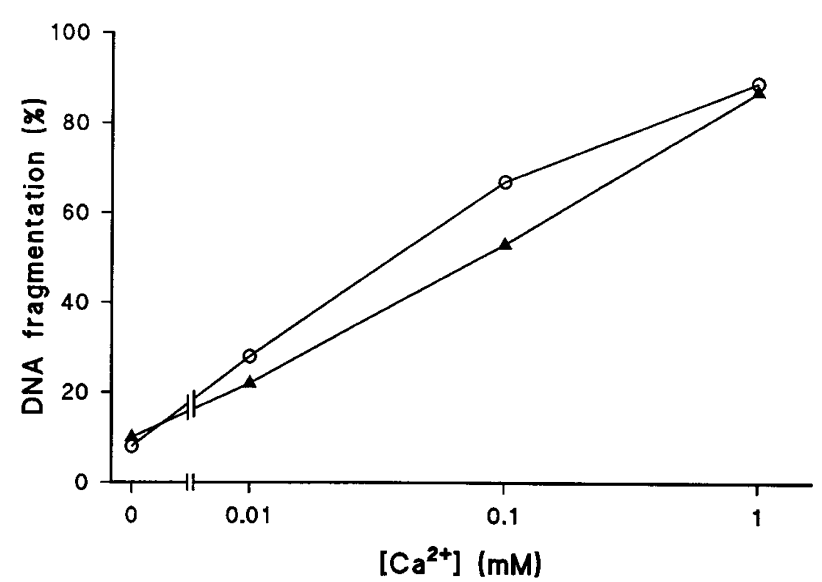

Figure 1 Lack of effect of TPEN on isolated thymocyte nuclei. Thymocyte nuclei were untreated (open circle) or treated with $10 \mu \mathrm{M}$ TPEN (closed triangle) in the presence or absence of different concentrations of $\mathrm{CaCl}_{2}$ for $2 \mathrm{~h}$. DNA fragmentation was quantitated by diphenylamine assay as described in Materials and Methods. The results are the means of duplicate samples from one of three separate nuclei preparations. 
proteases, since they are involved in many other examples of apoptosis (Martin and Green, 1995). Previous studies using cell-free systems suggest that ICE-like proteases are the active components in cytosolic extracts which cause nuclei to undergo apoptotic degradation (Martin et al, 1995; Schlegel et al, 1996). To investigate the possible involvement of ICE-like proteases in TPEN-triggered apoptosis, the effects of the protease inhibitor, Z-Val-Ala-Asp-chloromethylketone (VADcmk), was studied in this system. Thymocytes were treated with TPEN in the presence or absence of VADcmk. Thereafter, the formation of high molecular weight (HMW) and oligonucleosomal DNA fragments was examined. As shown in Figure $2 a$ and $b$, in the absence of VADcmk, TPEN induced the cleavage of DNA into HMW fragments $(700,300$, and $50 \mathrm{kbp}$ in length), which were then further degraded into oligonucleosomal DNA fragments. In the presence of VADcmk, the TPENinduced formation of $\mathrm{HMW}$ and oligonucleosomal DNA fragments was significantly reduced.

\section{PARP and lamin degradation and lack of involvement of a Ca ${ }^{2+}$-regulated serine protease in TPEN-induced apoptosis}

One of the substrates for ICE-like proteases is PARP (Lazebnik et al, 1994; Fernandes-Alnemri et al, 1995b; Gu et al, 1995). Cleavage of intact PARP (116 kDa) to an $85 \mathrm{kDa}$ fragment was observed in several apoptotic systems. In the present study, the proteolysis of PARP was studied in rat thymocytes treated with TPEN. As shown in Figure 3a, in control cells after incubation for $4 \mathrm{~h}$, the majority of PARP was intact $(116 \mathrm{kDa})$, although a small amount of $85 \mathrm{kDa}$ fragments could be detected, possibly resulting from spontaneous apoptosis occurring in these cells. Treatment of thymocytes with TPEN induced a loss of intact PARP and was accompanied by an increase in the formation of $85 \mathrm{kDa}$ fragments. VADcmk prevented the cleavage of PARP induced by TPEN, suggesting that this cleavage is also mediated by ICE-like proteases. a
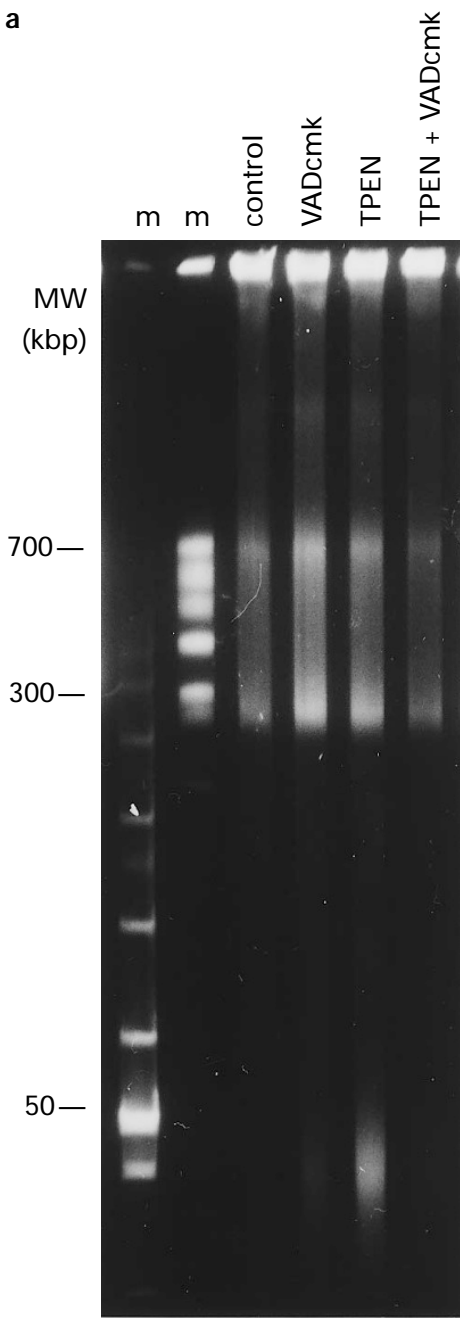

b

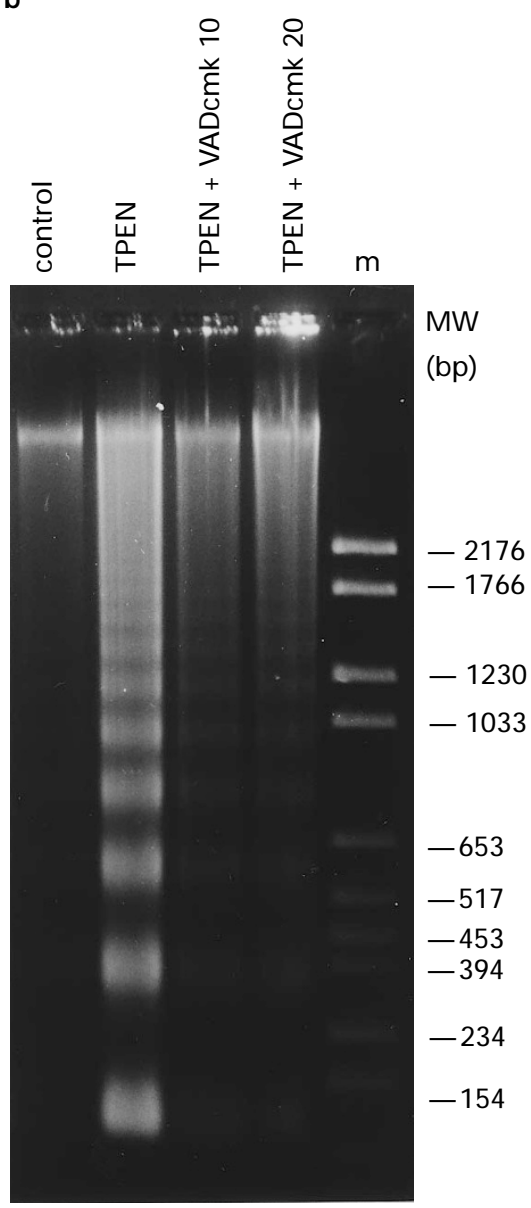

Figure 2 Involvement of ICE-like proteases in TPEN-induced apoptosis. Thymocytes were untreated or treated with $10 \mu \mathrm{M}$ TPEN in the presence or absence of 10 or $20 \mu \mathrm{M}$ VADcmk for $4 \mathrm{~h}$. HMW (a) and oligonucleosomal (b) DNA fragments were examined by FIGE and conventional agarose gel electrophoresis, respectively. $\mathrm{m}=$ markers. 
Lamin degradation occurs in cells undergoing mitosis (Gerace and Blobel, 1980). Recent studies have demonstrated that it is also an early event in apoptosis (Oberhammer et al, 1994; Neamati et al, 1995). As shown in Figure $3 \mathrm{~b}$, degradation of lamin $\mathrm{B}$ into $46 \mathrm{kDa}, 34 \mathrm{kDa}$ and $18 \mathrm{kDa}$ fragments was observed in our system. Lamin degradation first appeared in thymocytes treated with TPEN for $1 \mathrm{~h}$ and was present during incubation for up to $4 \mathrm{~h}$. VADcmk effectively abolished the TPEN-induced lamin breakdown, indicating that the activation of ICE-like proteases occurs prior to the lamin breakdown.

Clawson et al (1992) showed that a $\mathrm{Ca}^{2+}$-regulated nuclear scaffold serine protease can cleave lamin. To investigate whether the TPEN-induced lamin degradation is also mediated by this protease, the effects of its specific inhibitor, Suc-Ala-Ala-Pro-Phe-chloromethylketone (AAPFcmk) (Clawson et al, 1993) were then studied. As shown in Figure $3 \mathrm{~b}$, TPEN-induced lamin degradation was unaf-
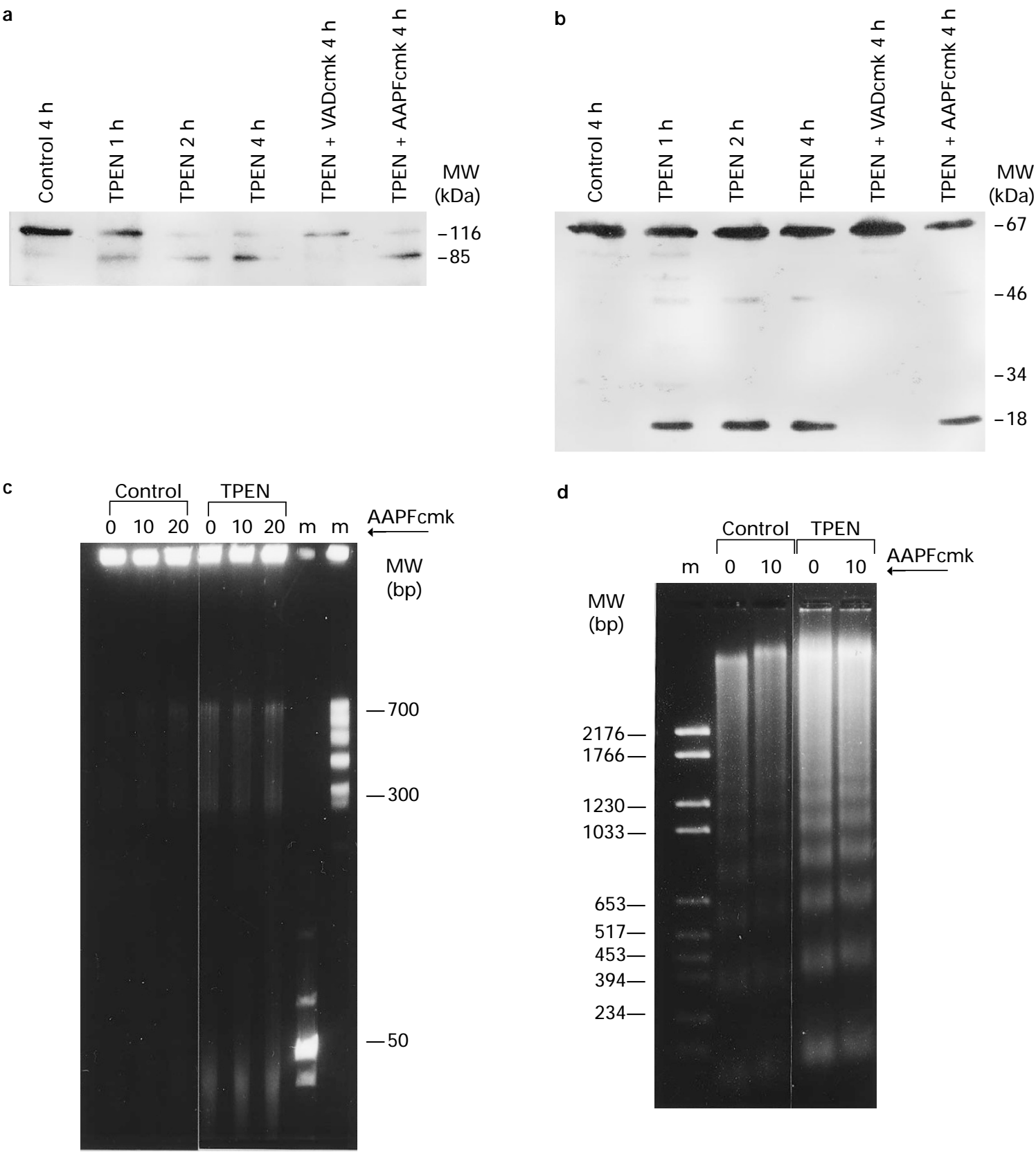

d

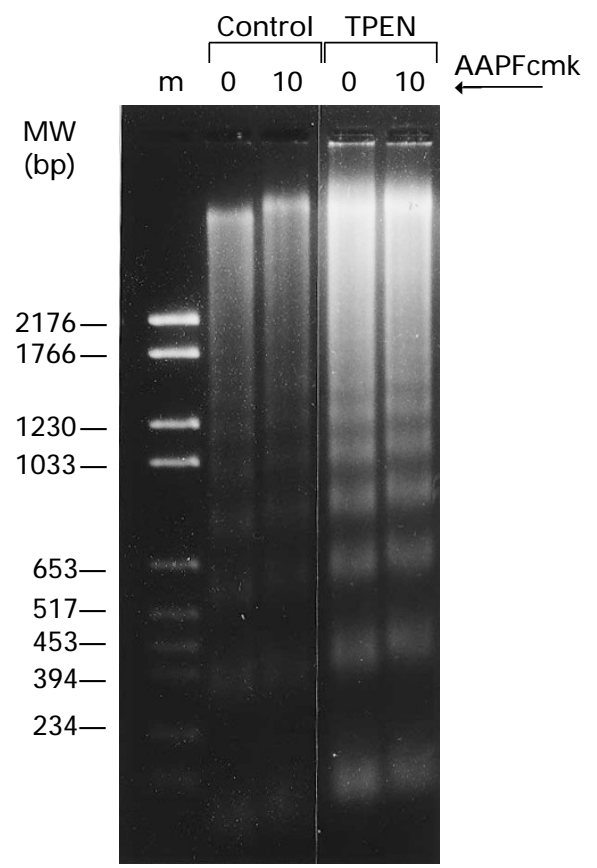

Figure 3 PARP and Lamin degradation and lack of effect of $\mathrm{Ca}^{2+}$-regulated serine protease inhibitors. Rat thymocytes were untreated, treated with $10 \mu \mathrm{M}$ TPEN alone for various times indicated, or treated with TPEN in the presence of $10 \mu \mathrm{M}$ VADcmk or $10 \mu \mathrm{M}$ AAPFcmk for $4 \mathrm{~h}$. PARP (a) and Lamin B (b) content was determined by immunoblotting. Rat thymocytes were untreated or treated with $10 \mu \mathrm{M}$ TPEN in the presence or absence of 10 or $20 \mu \mathrm{M} \mathrm{AAPFcmk}$. After $4 \mathrm{~h}$, the DNA was examined either by FIGE for the presence of HMW DNA fragments (c) or by agarose gel electrophoresis for the presence of DNA laddering (d) $m=$ markers. 
fected by AAPFcmk. Likewise, AAPFcmk was unable to prevent the formation of HMW and oligonucleosomal DNA fragments by TPEN (Figure $3 c$ and d). In addition, we found that this protease was not involved in TPEN-induced PARP cleavage (Figure 3a). Lack of involvement of $\mathrm{Ca}^{2+}$ regulated serine protease in TPEN-induced apoptosis is in agreement with our previous finding, which shows that $\mathrm{Ca}^{2+}$ is not a mediator of apoptosis in this system (Jiang et al, 1995).

\section{Induction of DNA fragmentation in isolated thymocyte nuclei by a cytosolic extract from TPEN-treated Jurkat cells}

Dissection of the molecular events which occur during apoptosis is facilitated by the use of cell-free systems (Earnshaw et al, 1995). In our present study, this approach was applied to examine whether the cytosolic extracts from TPEN-treated cells were capable of inducing DNA fragmentation in isolated nuclei from untreated cells. Jurkat cells, which have more cytoplasm than thymocytes, were used as a source of cytosolic extract. We first examined whether TPEN was able to trigger apoptosis in these cells. Jurkat cells were incubated in the presence of 2.5 or $10 \mu \mathrm{M}$ TPEN for various time periods and the DNA was analyzed. As shown in Figure 4, DNA cleavage into oligonucleosomal fragments was observed in Jurkat cells after treatment with $10 \mu \mathrm{M}$ TPEN for $4 \mathrm{~h}$. The cytosolic fractions were extracted from Jurkat cells, untreated or treated with TPEN for $4 \mathrm{~h}$, and their ability to induce DNA fragmentation in isolated untreated thymocyte nuclei was examined. As shown in Figure 5a, the cytosolic extract from TPEN-treated Jurkat cells was found to produce DNA fragmentation in isolated thymocyte nuclei, while an identically prepared cytosolic extract from untreated Jurkat cells was incapable of inducing DNA fragmentation. Since TPEN was unable to cause DNA fragmentation in isolated thymocyte nuclei (Figure 1), the possibility that TPEN contamination of the Jurkat cytosols caused DNA fragmentation can be effectively excluded. The addition of $10 \mu \mathrm{M}$ TPEN to the cytosol fraction from untreated Jurkat cells also failed to induce DNA cleavage in thymocyte nuclei (Figure $5 \mathrm{~b}$ ).

\section{Effects of inhibitors of ICE-like proteases on the apoptosis-inducing activity in TPEN-treated Jurkat cells}

Similar to the rat thymocyte experiments, VADcmk was effective in inhibiting the TPEN-induced DNA fragmentation in Jurkat cells (Figure 6). DNA fragmentation induced by TPEN was also blocked by another inhibitor of ICE-like proteases, Ac-Asp-Glu-Val-Asp-aldehyde (DEVD-CHO), which has been found to competitively inhibit CPP32/apopain (Nicholson et al, 1995). To investigate whether the inhibitors of ICE-like proteases could also affect the apoptosis-inducing activity present in cytosolic extract from TPEN-treated Jurkat cells, these inhibitors were added to cell cultures before or simultaneously with TPEN. After $4 \mathrm{~h}$, the cytosolic extracts were prepared from each sample. As shown in Figure 7, no apoptosis-inducing activity was detected in the cytosolic extract from cells treated with TPEN in the presence of VADcmk or DEVD-CHO. The involvement of ICE-like proteases in TPEN-treated cytosolic extract was further examined by incubating nuclei with this extract in the presence of VADcmk or DEVD-CHO. A partial decrease in DNA fragmentation was observed in the samples which included VADcmk or DEVD-CHO (data not shown), suggesting that ICE-like proteases are components of the active cytosolic extract. Similar to that observed with rat thymocytes, AAPFcmk was unable to prevent TPEN-induced DNA fragmentation in Jurkat cells, indicating the lack of involvement of $\mathrm{Ca}^{2+}$-regulated serine protease in this process (Figure $6)$.

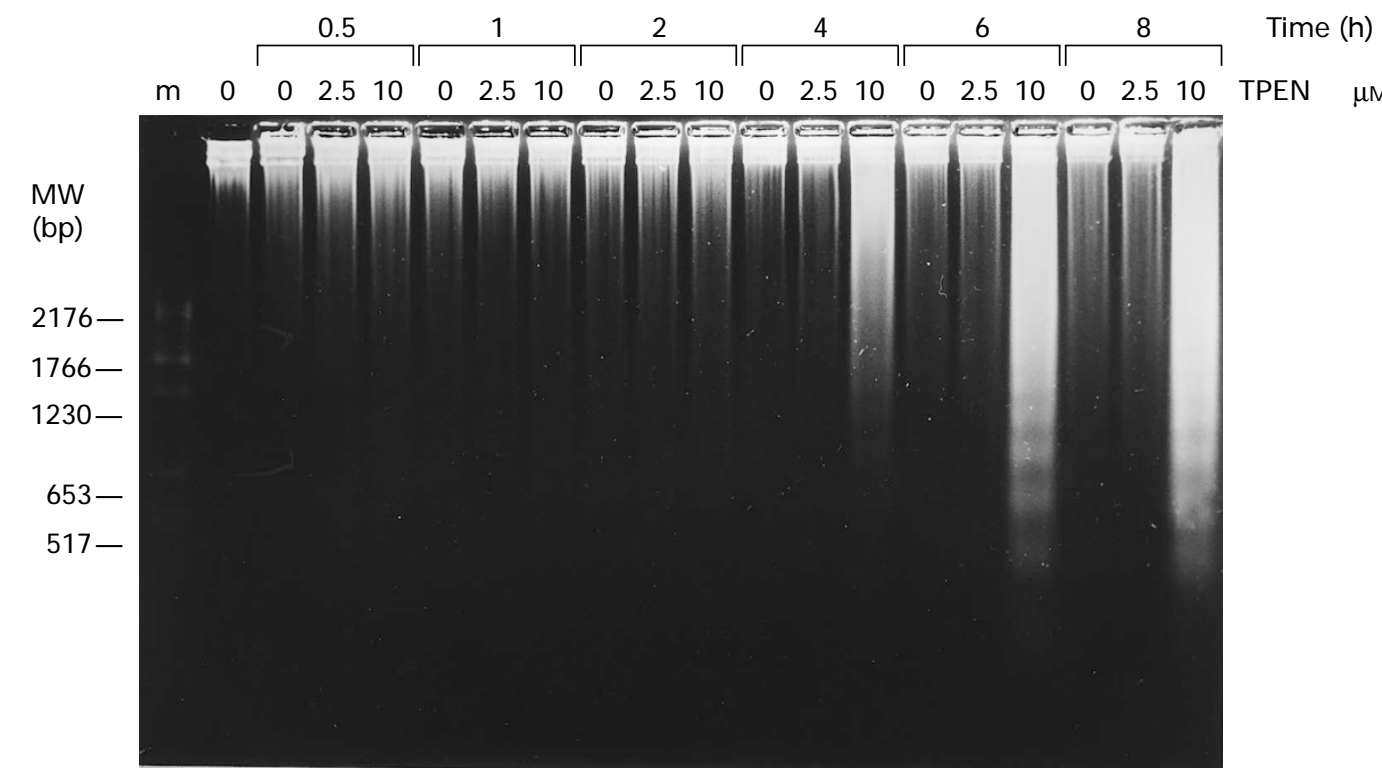

Figure 4 Time course of TPEN-induced DNA fragmentation in Jurkat cells. Jurkat cells were untreated or treated with 2.5 or $10 \mu \mathrm{M}$ TPEN for various time periods The formation of oligonucleosomal DNA fragments was examined by agarose gel electrophoresis. $\mathrm{m}=$ marker. 
a
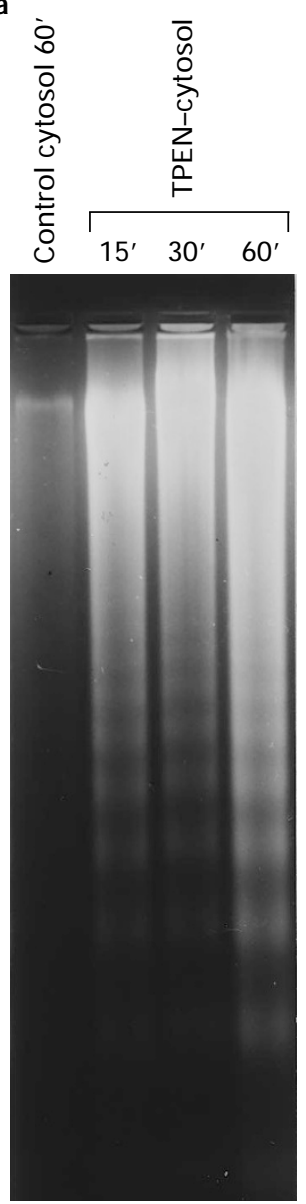

b

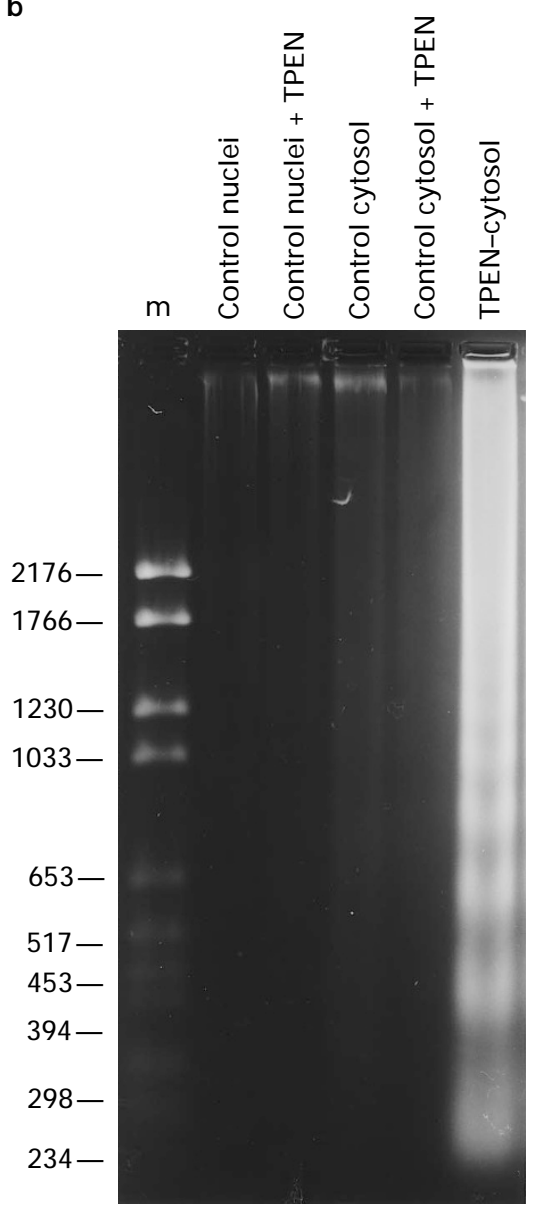

Figure 5 Induction of DNA fragmentation in isolated rat thymocyte nuclei by cytoplasmic extract from TPEN-treated Jurkat cells. Cytosolic extracts were prepared from Jurkat cells untreated (control cytosol) or treated with TPEN (TPEN cytosol) for $4 \mathrm{~h}$. Isolated thymocyte nuclei were incubated with these cytosolic extracts for various times indicated (a), or incubated with nothing, $10 \mu \mathrm{M}$ TPEN, or these cytosolic extracts in the absence or presence of TPEN for $1 \mathrm{~h}$ (b). The formation of oligonucleosomal DNA fragments was then assayed by conventional agarose gel electrophoresis as described in Materials and Methods. $\mathrm{m}=$ marker.

\section{Involvement of CPP32/apopain in TPEN-triggered apoptosis}

In order to identify the ICE-like proteases involved in TPENinduced apoptosis, the enzyme activity that cleaves Ac-AspGlu-Val-Asp-7-amino-4-methylcoumarin (DEVD-AMC), a fluorogenic substrate of CPP32/apopain and $M c h 3 \alpha$, was measured in both TPEN-treated thymocytes and Jurkat cells using a continuous fluorometric assay. As shown in Table 1, an increase in AMC release, which corresponded to the increase in enzyme activity, was observed in both types of cells treated with TPEN. Exposure of rat thymocytes to TPEN for 40 min induced AMC release, whereas in control cells no enzyme activity was detected at this time point. Prolonged incubation induced an increase in AMC release in control rat thymocytes, which correlated with spontaneous apoptosis in these cells. However, a greater increase in enzyme activity was observed in the TPEN-treated thymocytes at these time points. The increase in AMC release was inhibited by including $50 \mathrm{nM}$ DEVD-CHO in the reaction mixture (data not shown). In untreated Jurkat cells no enzyme activity was detected throughout the time of investigation. However, incubation of Jurkat cells for $40 \mathrm{~min}$ in the presence of TPEN caused a release of AMC from substrate, which increased several fold in $2 \mathrm{~h}$ (Table 1). Compared to thymocytes, the increase in the enzyme activity by TPEN in Jurkat cells was much less. In cytosolic extracts from TPEN-treated Jurkat cells, the enzyme activity that cleaves DEVD-AMC was also detected (Table 2). The addition of DEVD-CHO to this extract partially inhibited the enzyme activity. The control cytosol from untreated Jurkat cells contained little enzyme activity. The addition of TPEN to control cytosol failed to increase the AMC release.

The proenzyme, CPP32, has been identified as a native $32 \mathrm{kDa}$ protein. The activation of this enzyme includes the cleavage of $32 \mathrm{kDa}$ precursor resulting in two subunits of relative molecular mass $17 \mathrm{kDa}$ and $12 \mathrm{kDa}$, respectively, followed by the formation of tetramers (Nicholson et al, 1995). Immunoblot analysis using antibody against the $32 \mathrm{kDa}$ protein shows the presence of native polypeptide in 
the extracts from untreated Jurkat cells and the disappearance of this protein in cells treated with TPEN (Figure $8 \mathrm{~B})$. However, in the extracts prepared from cells that were treated with TPEN in the presence of VADcmk or DEVD$\mathrm{CHO}$, the native CPP32 was detected. Since this antibody was unable to recognize the cleavage products of CPP32, in the next experiment membranes were probed with the monoclonal antibodies to p17 and p12 (Figure 8b and c). The native CPP32 protein was again found in the extracts from untreated cells. In the cytosolic extracts from TPENtreated Jurkat cells, the proteins with molecular mass corresponding to both $\mathrm{p} 17$ and $\mathrm{p} 12$ were present. It is known that CPP32 is initially processed with the formation of p20 and p12, followed by conversion of p20 to p17 (Nicholson et al, 1995). Immunoblots stained with antibody against p17 and p12 show the presence of p20 in the cytosolic extracts from TPEN-treated Jurkat cells (Figure $8 \mathrm{~b}$ and $\mathrm{c})$. The formation of $\mathrm{p} 17$ and $\mathrm{p} 12$ was effectively

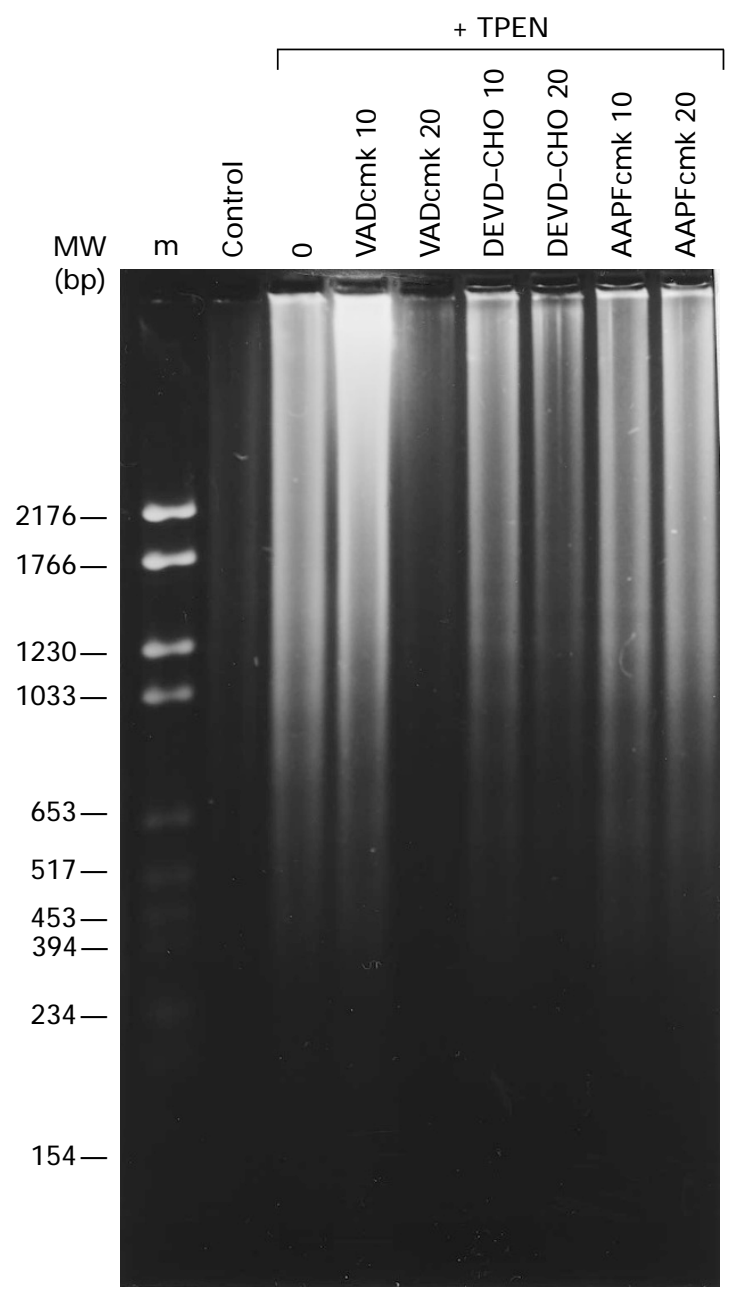

Figure 6 Effects of inhibitors of ICE-like proteases on TPEN-induced DNA fragmentation in Jurkat cells. Jurkat cells were untreated or treated with $10 \mu \mathrm{M}$ TPEN in the presence or absence $(\mu \mathrm{M})$ of VADcmk, DEVD-CHO, or AAPFcmk for $6 \mathrm{~h}$. Oligonucleosomal DNA fragmentation was examined by conventional agarose gel electrophoresis. $m=$ marker. blocked and these proteins were not detected in the cytosolic extract from cells that were treated with TPEN in the presence of VADcmk or DEVD-CHO (Figure $8 \mathrm{~b}$ and $\mathrm{c}$ ).

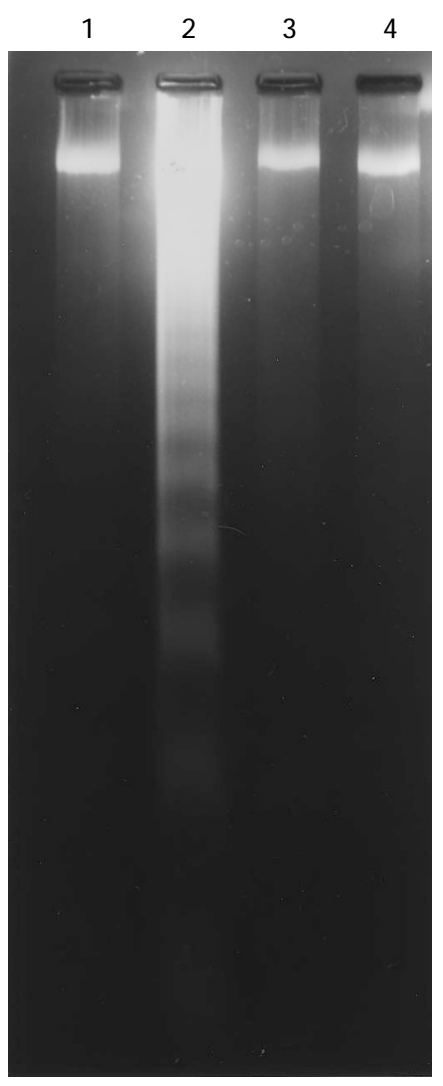

Figure 7 Effects of inhibitors of ICE-like proteases on apoptosis-inducing activity in TPEN-treated Jurkat cells. Jurkat cells were untreated (lane 1) or treated with $10 \mu \mathrm{M}$ TPEN (lanes 2-4) in the absence (lane 2) or presence of $10 \mu \mathrm{M}$ VADcmk (lane 3) or $10 \mu \mathrm{M}$ DEVD-CHO (lane 4) for $4 \mathrm{~h}$. Cytosolic extracts were prepared from each sample and incubated with isolated thymocyte nuclei for $1 \mathrm{~h}$. Their ability to induce DNA fragmentation in isolated thymocyte nuclei was examined by conventional agarose gel electrophoresis.

Table 1 DEVD-AMC cleavage in TPEN-treated rat thymocytes and Jurkat cells

\begin{tabular}{lcc}
\hline & \multicolumn{2}{c}{ AMC release (pmol/min) } \\
Time (min) & Control & TPEN \\
\hline (A) Thymocytes & & \\
40 & 0 & 8.6 \\
100 & 18.9 & 36.8 \\
140 & 31.0 & 62.2 \\
& & \\
(B) Jurkat cells & & \\
40 & 0 & 2.5 \\
90 & 0 & 4.3 \\
120 & 0 & 6.6 \\
150 & 0 & 7.6 \\
\hline
\end{tabular}

Thymocytes and Jurkat cells $\left(5 \times 10^{6}\right.$ cells $\left./ \mathrm{ml}\right)$ were untreated or treated with $10 \mu \mathrm{M}$ TPEN for the various times indicated. AMC release was measured as described in Materials and Methods. The results are from one representative experiment out of two. 


\section{Discussion}

Our present study shows that in TPEN-triggered thymocyte apoptosis DNA fragmentation is not induced by the direct effects of TPEN on nuclei, but rather by the activation of

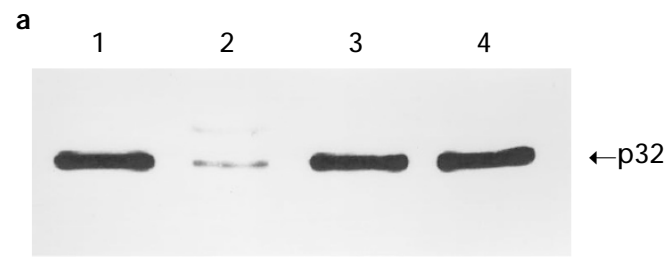

b

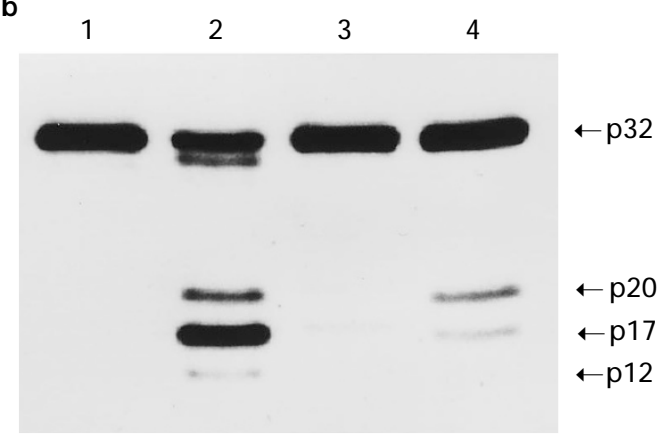

C

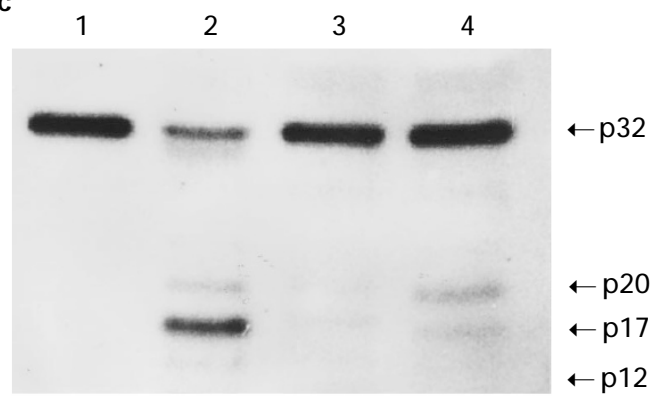

Figure 8 CPP32 cleavage in cytosolic extract from TPEN-treated Jurkat cells and the effects of inhibitors of ICE-like proteases. Jurkat cells were untreated (lane 1) or treated with $10 \mu \mathrm{M}$ TPEN (lanes 2-4) in the absence (lane 2) or presence of $10 \mu \mathrm{M}$ VADcmk (lane 3) or $10 \mu \mathrm{M}$ DEVD-CHO (lane 4 ) for $4 \mathrm{~h}$. Cytosolic extracts were prepared from these cells. The presence of CPP32 and the fragments of its proteolytical cleavage was determined by immunoblotting using anti-CPP32 (a), anti-p17 (b), or anti-p12 (c) antibodies.

Table 2 DEVD-AMC cleavage in cytosolic extracts from TPEN-treated Jurkat cells

\begin{tabular}{lc}
\hline Time $(\mathbf{m i n})$ & AMC release $(\mathbf{p m o l} / \mathbf{m i n})$ \\
\hline Control cytosol & 0.64 \\
Control cytosol+TPEN & 0.56 \\
TPEN cytosol & 38.3 \\
TPEN cytosol+DEVD-CHO & 15.4 \\
\hline
\end{tabular}

Cytosolic extracts were prepared from Jurkat cells untreated (control cytosol) or treated with $10 \mu \mathrm{M}$ TPEN (TPEN cytosol) for $4 \mathrm{~h}$. Cytosolic extracts were then incubated with or without $10 \mu \mathrm{M}$ TPEN for $1 \mathrm{~h}$. AMC release was measured in the absence or presence of $50 \mathrm{nM}$ DEVD-CHO as described in Materials and Methods. The results are from one representative experiment out of two. cytosolic effectors. Activation of these cytosolic effectors by TPEN occurs only in intact cells, since the addition of TPEN to cytosolic extract from untreated cells was unable to induce DNA fragmentation in isolated nuclei. It suggests that TPEN cannot directly activate the cytosolic component(s) required to induce DNA fragmentation in the isolated nuclear fraction. This is unlike the systems described by Bertrand et al (1994) and Martin et al (1995). In their respective systems, they found that apoptotic activity could be induced by cytoplasmic extract from untreated cells following either the addition of staurosporine, a broad-spectrum protein kinase inhibitor, or the addition of ceramide, a lipid second messenger. However, although ceramide could induce apoptotic activity in normal cell extracts, the morphological changes in the nuclei were not as dramatic as those observed when extracts from UV- or anti-Fas antibody-primed cells were employed (Martin et al, 1995).

From our results, it is clear that the cytosolic extract from TPEN-treated cells contains ICE-like proteolytic activity. Whether ICE-like proteases are also required for the formation of the apoptosis-inducing activity in this cytosolic extract is not known. The apoptosis-inducing activity in cytosolic fraction from TPEN-treated Jurkat cells was blocked by incubating cells in the presence of inhibitors of ICE-like proteases. The abolishment of apoptosisinducing activity by protease inhibitors may be due to the inhibition of production of active effectors of apoptosis in TPEN-treated Jurkat cells. However, we cannot exclude the possibility that active effectors were generated but that their effect on the isolated nuclei was blocked by the inhibitors present in the cytosol.

Currently, we do not know how ICE-like proteases are activated in TPEN-treated cells. An in vitro study by Black et al (1989) showed that the metal chelators EDTA and 1,10-phenanthroline, which both chelate $\mathrm{Zn}^{2+}$, completely inhibit ICE activity. Moreover, we found that TPEN was unable to directly activate cytosolic components, i.e. proteases, from untreated Jurkat $T$ cells to induce DNA fragmentation in isolated nuclei. Thus, the increase of ICElike protease activity in the TPEN system was probably not due to a direct effect of TPEN. The inhibition of DNA fragmentation by DEVD-CHO both in vivo and in vitro indicates the involvement of CPP32 in TPEN-induced apoptosis. DEVD-CHO has low membrane permeability (Nicholson et al, 1995), and its effect on intact Jurkat cells may be due to the high concentration which we used $(10 \mu \mathrm{M})$. However, the involvement of CPP32 in TPENinduced apoptosis was strongly supported by an increase in enzyme activity which cleaves DEVD-AMC, a fluorogenic substrate of CPP32/apopain, and the cleavage of CPP32 into $\mathrm{p} 17$ and $\mathrm{p} 12$ fragments. The activation of a protease which cleaves DEVD-AMC was observed in both thymocytes and Jurkat cells treated with TPEN. This activity was inhibited by DEVD-CHO. It is known that CPP32 activation involves proteolysis and the formation of two polypeptides, p17 and p12. In fact, the active cytosolic extract from Jurkat cells treated with TPEN contained a small amount of the native CPP32 and greater amounts of $\mathrm{p} 17$ and $\mathrm{p} 12$. The activation of CPP32 registered as a formation of $\mathrm{p} 17$ and p12, was blocked by two inhibitors, VADcmk and DEVD- 
$\mathrm{CHO}$. Therefore, TPEN-triggered apoptosis is also mediated by the activation of a CPP32-like protease.

One of the proteins that is known to be cleaved by CPP32/apopain is PARP. PARP is an enzyme involved in DNA repair (D'Murcia and D'Murcia, 1994). Using NAD ${ }^{+}$as a substrate, this enzyme links poly(ADP-ribose) moieties to cleave sites in the DNA backbone, presumably allowing for the short term maintenance of structural integrity until DNA polymerases can make permanent repairs. Importantly, PARP is a zinc binding enzyme and has two zinc fingers near its N-terminus, defining the domain that binds to DNA breaks with nanomolar affinity (D'Murcia and D'Murcia, 1994). Activation of CPP32/apopain induces the cleavage of PARP from the $116 \mathrm{kDa}$ active form to an $85 \mathrm{kDa}$ carboxy-terminal fragment and a small fragment containing the zinc fingers (Lazebnik et al, 1994). It is suggested that the generation of these small fragments might enhance cell death in conjunction with DNA fragmentation (Lindahl et al, 1995). In TPEN-treated rat thymocytes, PARP underwent a similar pattern of cleavage, which could be blocked by the inhibitor of ICE-like proteases. These data suggest that the TPEN-induced PARP cleavage is mediated by ICE-like proteases, but not by a direct effect of TPEN on PARP.

It is not clear whether the activation of ICE-like proteases also contributes to the activation of proteases involved in lamin degradation. Our data show that TPENinduced lamin degradation was inhibited by VADcmk, suggesting that the activation of ICE-like proteases occurs prior to lamin degradation. The lamin degradation in TPENinduced apoptosis was not due to an activation of the $\mathrm{Ca}^{2+}$. regulated serine protease, as demonstrated by the lack of effect of AAPFcmk. It is possible that another $\mathrm{Ca}^{2+}$ independent protease may be used to cleave lamin in the TPEN system. A recent study by Lazebnik et al (1995) demonstrated that a $\mathrm{Ca}^{2+}$-regulated serine protease is not the only enzyme capable of cleaving lamin during apoptosis. In their study, no inhibition of lamin cleavage by AAPFcmk was observed, which is similar to what we observed in the TPEN system. Nevertheless, we found the involvement of $\mathrm{Ca}^{2+}$-regulated serine protease in systems where apoptosis is associated with an increase of cytosolic free $\mathrm{Ca}^{2+}$ concentration, such as thymocyte apoptosis induced by glucocorticoid and thapsigargin (Zhivotovsky et al, 1995; S. Jiang, B. Zhivotovsky, A. Gahm, and S. Orrenius unpublished data).

TPEN induces neither oligonucleosomal DNA fragmentation in isolated rat thymocyte nuclei (Figures 1 and 5) nor single or double strand DNA breaks in isolated liver nuclei (Burkitt et al, 1996). Nevertheless, it is possible that in whole cells TPEN can result in early damage to DNA not detectable as HMW or oligonucleosomal DNA fragments. Thus, we can not exclude the possibility that early DNA damage serves as a signal thereby initiating the activation of cytosolic ICE-like proteases, as suggested in apoptosis induced by the topoisomerase inhibitor, etoposide (Zhivotovsky et al, 1995). We found that TPEN- and etoposideinduced apoptosis share many features. Both involve an early activation of ICE-like proteases and degradation of nuclear lamins prior to DNA cleavage, which are not prevented by a $\mathrm{Ca}^{2+}$-regulated serine protease inhibitor
(Zhivotovsky et al, 1995). The signal initiating the activation of cytosolic ICE-like proteases could be also from the cell surface. Zinc has been found to significantly affect the cell membrane by interfering with macromolecular components of the membrane, thus changing their conformation or enzyme-substrate specificity (Bettger and O'Dell, 1981). Therefore, it is possible that chelation of $\mathrm{Zn}^{2+}$ by TPEN may activate ICE-like proteases by a pathway similar to that triggered by receptor-mediated apoptotic stimuli, for example, anti-Fas antibody.

In conclusion, our study demonstrates that the mechanism whereby TPEN triggers apoptosis does not involve its direct effects on nuclei. An activation of cytosolic effectors, which include CPP32/apopain, is essential for initiating apoptosis in the TPEN system. Our results provide strong evidence that, as in several other systems, ICE-like proteases play a central role in TPENinduced apoptosis.

\section{Materials and Methods}

\section{Materials}

RPMI 1640 medium and fetal bovine serum (FBS) were obtained from Gibco BRL (Gaithersburg, MD, USA). TPEN and Pulse markers chromosomes from Saccharomyces cerevisiae (225-2200 kbp) and a mixture of $\lambda D N A$ Hindlll fragments, $\lambda D N A$, and $\lambda D N A$ concatemers $(0.1-200 \mathrm{kbp})$ were purchased from Sigma Chemical Co. (St. Louis, MO, USA). Molecular weight markers VI (pBR 328 DNA/Bg/I - Hinf I) and proteinase $K$ were obtained from Boehringer-Mannheim (Mannheim, Germany). RNAse and pronase were purchased from Calbiochem (La Jolla, CA, USA). VADcmk and AAPFcmk were obtained from Enzyme System Products (Dublin, CA, USA). ECL was from Amersham Corp. (Buckinghamshire, UK). Antibody against lamin B1 was generously provided by $\mathrm{Dr}$. Scott $\mathrm{H}$. Kaufmann (The Mayo Clinic, Rochester, MN, USA). Anti-PARP antibody was kindly provided by Dr. Guy G. Poirier (Laval University, Quebec, Canada). Anti-p17 and p12 antibody were kindly donated by Dr. Donald W. Nicholson (Merck Frosst Center for Therapeutic Research, Quebec, Canada). Goat anti-mouse IgG-HRP was from Pierce (Rockford, IL, USA). Human anti-CPP32 antibody was from Transduction Laboratories (Lexington, KY, USA). Goat anti-chicken IgG-HRP was from Southern Biotechnology Associates, Inc. (Birmingham, AL, USA). Rabbit antihuman IgG-HRP was from Dakopatts A/S (Denmark). DEVD-CHO was from Merck Research Laboratory (Rahway, NJ, USA). DEVD-AMC was from Bachem (Bubendorf, Switzerland). All other reagents were from local sources and were of the highest purity available.

\section{Cells and culture conditions}

Cells were cultured in RPMI 1640 medium supplemented with FBS, $2 \mathrm{mM}$ glutamine, $100 \mathrm{IU} / \mathrm{ml}$ penicillin and $100 \mu \mathrm{g} / \mathrm{ml}$ streptomycin in a humidified incubator $\left(37^{\circ} \mathrm{C}\right)$ at an atmosphere of $5 \% \mathrm{CO}_{2}$ in air. Thymocytes were prepared from thymic glands from male SpragueDawley rats $(75-85 \mathrm{~g})$ as described previously (McCabe et al, 1993) and incubated with the aforementioned agents at a density of $5 \times 10^{6}$ cells/ml in RPMI 1640 medium supplemented with $2 \%$ FBS. Human leukemia T cell line, Jurkat, was obtained from ATCC (Rockville, MD, USA) and maintained in suspension culture using RPMI 1640 medium supplemented with $10 \%$ FBS. 


\section{Isolation of thymocyte nuclei}

Rat thymocyte nuclei were prepared as described previously by Alnemri and Litwack (1990) with the following modifications: 1) $0.02 \%$ NP-40 was added to thymocytes before homogenization and in the buffer used to prepare nuclei and 2) PMSF was omitted. The isolated nuclei were then resuspended in buffer $\mathrm{B}\left(5 \mathrm{mM} \mathrm{MgCl}_{2}, 2.1 \mathrm{M}\right.$ sucrose, $50 \mathrm{mM}$ Tris, $\mathrm{pH} 7.5$ ) at a final density of $3-4 \times 10^{8}$ nuclei $/ \mathrm{ml}$ before use.

\section{Quantitation of DNA fragmentation}

DNA fragmentation in thymocyte nuclei was measured by diphenylamine assay. Briefly described, thymocyte nuclei $\left(5 \times 10^{6}\right)$ $\mathrm{ml}$ ) were incubated at $37^{\circ} \mathrm{C}$ in the incubating buffer $(25 \mathrm{mM}$ Hepes, $\mathrm{pH} 7.2,2 \mathrm{mM}$ potasium phosphate, $125 \mathrm{mM} \mathrm{KCl}, 4 \mathrm{mM} \mathrm{MgCl}_{2}$ ) with $10 \mu \mathrm{M}$ TPEN and/or various concentrations of $\mathrm{CaCl}_{2}$ for $2 \mathrm{~h}$. Aliquots of $0.8 \mathrm{ml}$ nuclei suspension were added to $0.7 \mathrm{ml}$ ice-cold lysis buffer containing $20 \mathrm{mM}$ EDTA, $0.05 \%$ (v/v) Triton X-100 and $10 \mathrm{mM}$ Tris- $\mathrm{Cl}$ at $\mathrm{pH}$ 8.0. The nuclei were allowed to lyse for $15 \mathrm{~min}$ at $4{ }^{\circ} \mathrm{C}$ prior to centrifugation for $15 \mathrm{~min}$ at $13,000 \times g$ to separate the intact chromatin (pellet) from DNA fragments in the supernatants. The DNA in the pellets and supernatants was digested with $5 \%$ trichloroacetic acid before being assayed using the diphenylamine reagent (Burton, 1956).

\section{Analysis of oligonucleosomal DNA fragments}

The formation of oligonucleosomal DNA fragments was examined by agarose gel electrophoresis. Briefly, after incubation with agents where indicated, $2 \times 10^{6}$ cells or nuclei were resuspended in $250 \mu \mathrm{l}$ of TE buffer (10 mM Tris and $1 \mathrm{mM}$ EDTA at pH 8.0). The suspensions were then mixed with an equal volume of lysis buffer (see above). After $30 \mathrm{~min}$ on ice, the lysates were centrifuged for $15 \mathrm{~min}$ at $4^{\circ} \mathrm{C}$ at $13,000 \times g$ to separate cell debris containing intact chromatin (pellet) from DNA fragments (supernatant). The fragmented DNA in supernatant was precipitated overnight at $-20^{\circ} \mathrm{C}$ with ethanol. Next, the DNA was resuspended in $20 \mu \mathrm{l}$ TE buffer (see above), incubated subsequently with $1 \mu \mathrm{l} 50 \mathrm{mg} / \mathrm{ml}$ RNAse $A$ for $1 \mathrm{~h}$ at $37^{\circ} \mathrm{C}$, and thereafter $1 \mu \mathrm{l} 25 \mathrm{mg} / \mathrm{ml}$ proteinase $\mathrm{K}$ was added and incubated for $1 \mathrm{~h}$ at $37^{\circ} \mathrm{C}$. The samples were electrophorezed for $4 \mathrm{~h}$ at $60 \mathrm{~mA}$ on $1.8 \%$ agarose gels. The separated DNA was stained with $1 \mu \mathrm{g} / \mathrm{ml}$ ethidium bromide and visualized by UV light.

\section{Field inversion gel electrophoresis (FIGE)}

Thymocytes were incubated with agents as previously indicated for $4 \mathrm{~h}$, washed and then resuspended in $250 \mu \mathrm{l}$ prewarmed phosphate buffered solution. An equal volume of liquified $1 \%$ low-melting point agarose solution was added to this suspension and gently mixed. One hundred microliters of mixture were dispensed to each well of the insert moulds, and allowed to $\mathrm{cool}$ on ice for $30 \mathrm{~min}$. The resulting agarose plugs were dislodged from the insert moulds, transferred into a solution containing $1 \%$ lauryl sarcosine, $0.5 \mathrm{M}$ EDTA, $10 \mathrm{mM}$ Tris, and $1 \mathrm{mg} / \mathrm{ml}$ pronase, and incubated at $50^{\circ} \mathrm{C}$ with continuous agitation. After $24 \mathrm{~h}$, the old solution was replaced with a fresh one and incubation was continued for another $24 \mathrm{~h}$. In a similar solution as above but without pronase, the plugs were rinsed twice for $2 \mathrm{~h}$ per rinse and stored at $4^{\circ} \mathrm{C}$ until use. Before electrophoresis, the plugs were washed three times in a buffer containing $10 \mathrm{mM}$ Tris and $1 \mathrm{mM}$ EDTA. FIGE was carried out using a horizontal (HE 100B) gel chamber, a power supply (PS 500XT) and switchback pulse controller (PC 500, Hoefer Scientific Instruments, U.S.A.). The temperature was controlled by an LKB 2209 Multitemp constant temperature cooling system. Electrophoresis was run at $200 \mathrm{~V}$ in $1 \%$ agarose gel in $0.5 \times$ TBE $(4.45 \mathrm{mM}$ Tris, $4.45 \mathrm{mM}$ boric acid, and $1.25 \mathrm{mM}$ EDTA, $\mathrm{pH} 8.5)$ at $14^{\circ} \mathrm{C}$ with the ramping rate changing from $0.8 \mathrm{~s}$ to $30 \mathrm{~s}$ over a $24 \mathrm{~h}$ period, applying a forward to reverse ratio of $3: 1$. DNA size calibration was performed using two sets of pulse markers: chromosomes from Saccharomyces cerevisiae (225-2200 kbp), and a mixture of $\lambda$ DNA Hindlll fragments, $\lambda$ DNA and $\lambda$ DNA concatemers $(0.1-200 \mathrm{kbp})$. DNA was stained with $1 \mu \mathrm{g} / \mathrm{ml}$ ethidium bromide and visualized using UV light.

\section{Immunoblot analysis}

For protein detection with Western Blot, cells were homogenized in low salt buffer (10 mM HEPES, pH 8.0, $1 \mathrm{mM} \mathrm{MgCl} 2,20 \mathrm{mM} \mathrm{KCl}, 1 \mathrm{mM}$ DTT, $1 \mathrm{mM}$ PMSF, $1 \mathrm{mM}$ 1,10-phenanthroline, $20 \mu \mathrm{g} / \mathrm{ml}$ leupeptin, $5 \mu \mathrm{g} / \mathrm{ml}$ pepstatin, and $0.5 \% \mathrm{NP}-40$ ). Then, the cells were centrifuged at $2,000 \times g$ for $5 \mathrm{~min}$ at $4^{\circ} \mathrm{C}$. The pellets were washed once with a similar buffer as above but without NP-40. Both supernatants were combined and centrifuged at $12,000 \times g$ for $20 \mathrm{~min}$ at $4^{\circ} \mathrm{C}$. Insoluble protein fractions from the debris were extracted with high salt buffer $(0.4 \mathrm{M}$ $\mathrm{NaCl}, 20 \mathrm{mM}$ HEPES, pH 8.0, $1 \mathrm{mM} \mathrm{MgCl} 2,0.5 \mathrm{mM}$ EDTA, $0.5 \mathrm{mM}$ DTT, $1 \mathrm{mM}$ PMSF, $1 \mathrm{mM} \mathrm{1,10-phenanthroline,} 20 \mu \mathrm{g} / \mathrm{ml}$ leupeptin, $5 \mu \mathrm{g} / \mathrm{ml}$ pepstatin, and $0.1 \%$ NP-40) by incubating on ice for $40 \mathrm{~min}$ and thereafter centrifuging at $12,000 \times \mathrm{g}$ for $20 \mathrm{~min}$ at $4^{\circ} \mathrm{C}$. Extracted proteins were solubilized for $5 \mathrm{~min}$ at $100^{\circ} \mathrm{C}$ in Laemmli's SDS-PAGE sample buffer. Polypeptides were resolved at $130 \mathrm{~V}$ on $12 \%$ or $15 \%$ SDS-PAGE gels and electrophoretically transferred to nitrocellulose $(0.2 \mu \mathrm{m})$ for $2 \mathrm{~h}$ at $100 \mathrm{~V}$. Membranes were blocked overnight in a buffer ( $50 \mathrm{mM}$ Tris, $500 \mathrm{mM} \mathrm{NaCl}, \mathrm{pH} 7.5$ ) containing $1 \%$ bovine serum albumin and $5 \%$ non-fat dried milk. Then, the membranes were probed for $1.5 \mathrm{~h}$ with anti-lamin B1 Ab $(1: 500)$, anti-PARP Ab $(1: 5000)$, antiCPP32 Ab (1:100), anti-p17 Ab (1:5000), or p12 (1:1000) Ab and $1 \mathrm{~h}$ with HRP-conjugated secondary antibodies $(1: 10,000)$, and then visualized by ECL according to manufacturer's instructions.

\section{Preparation of cytosolic fraction}

Jurkat cells $\left(6 \times 10^{6}\right.$ cells $\left./ \mathrm{ml}\right)$ were treated with TPEN for $4 \mathrm{~h}$. The cells were then washed with ice-cold RPMI 1640 medium (without FBS) and resuspended $\left(6 \times 10^{6}\right.$ cells per $\left.10 \mu \mathrm{l}\right)$ in buffer $A(40 \mathrm{mM} \beta$ glycerophosphate, $50 \mathrm{mM} \mathrm{NaCl}, 2 \mathrm{mM} \mathrm{MgCl}$, $5 \mathrm{mM}$ EGTA, $10 \mathrm{mM}$ HEPES, pH 7.0). After four cycles of freezing and thawing in ethanol: dry ice bath, the cell lysates were centrifuged for $30 \mathrm{~min}$ at 20,000 $\times \mathrm{g}$ to pellet the membrane fraction. The supernatants were centrifuged for an additional $30 \mathrm{~min}$ at $100,000 \times g$ to obtain supernatant fraction consisting mainly of cytosolic proteins. The protein concentrations in the supernatants were measured using the BCA protein assay kit (Pierce).

\section{Reconstitution of the cell-free system}

Using a cell-free system as described by Lazebnik et al (1993), isolated nuclei were incubated with cytosolic fractions prepared from untreated or TPEN-treated Jurkat cells. The reaction mixture, containing $145 \mu \mathrm{g}$ of cytosolic proteins and $2 \times 10^{6}$ nuclei, was diluted to a final volume of $30 \mu \mathrm{l}$ with buffer $\mathrm{A}$ (see above) plus $2 \mathrm{mM}$ DTT, supplemented with an ATP-regeneration system. Samples were incubated at $37^{\circ} \mathrm{C}$ for the time periods indicated before analysis of the formation of oligonucleosomal DNA fragments. 


\section{Fluorometric assay of DEVD-AMC cleavage}

The enzyme activity that cleaves DEVD-AMC, a specific fluorogenic substrate for CPP32/apopain, was measured by a continuous fluorometric assay, which was modified from a method described by Nicholson et al (1995). The reaction mixture contained $40 \mu \mathrm{M}$ substrate, cell extract, and buffer (100 mM HEPES, pH 7.25, 10\% sucrose, $0.1 \%$ CHAPS, $10 \mathrm{mM}$ DTT). Liberation of AMC from the substrate was monitored continuously using an excitation wavelength of $355 \mathrm{~nm}$ and an emission wavelength of $460 \mathrm{~nm}$. The enzyme activity was shown as pmol of AMC release per min.

\section{Acknowledgements}

This study was supported by grants from the Swedish Medical Research Council (Project no: 03X-2471). The authors want to thank Dr. Scott Kaufmann for the kind gift of anti-lamin B1 antibody, Dr. Guy Poirer for the generous gift of anti-PARP antibodies, Dr. Donald Nicholson for generous supply of the p17 and p12 antibodies, Dr. Andrew Slater for critical review of this manuscript, and Elisabeth Wakeman and Anna Carin Hellerqvist for help with manuscript preparation.

\section{References}

Alnemri ES and Litwack GJ (1990) Activation of internucleosomal DNA cleavage in human CEM lymphocytes by glucocorticoid and novobiocin: Evidence for a non$\mathrm{Ca}^{2+}$-requiring mechanism(s). J. Biol. Chem. 265: 17323-17333

Arends MJ and Wyllie AH (1991) Apoptosis: Mechanisms and roles in pathology. Int. Rev. Exp. Pathol. 32: 223-254

Bertrand R, Solary E, O'Connor P, Kohn KW, and Pommier Y (1994) Induction of a common pathway of apoptosis by staurosporine. Exp. Cell Res. 211: 314-321

Bettger WJ and O'Dell BL (1981) A critical physiology role of zinc in the structure and function of biomembrane. Life Sci. 28: 1425-1438

Black RA, Kronheim SR, Merriam JE, March CJ and Hopp TP (1989) A pre-aspartatespecific protease from human leukocytes that cleave pro-interleukin-1 $\beta$. J. Biol. Chem. 264: 5323-5326

Brancolini C, Benedetti M and Schneider C (1995) Microfilament reorganization during apoptosis: the role of Gas2, a possible substrate for ICE-like proteases. EMBO J. 14: 5179-5190

Burkitt MJ, Miline L, Nicotera P and Orrenius S (1996) 1, 10-phenanthroline stimulates internucleosomal DNA fragmentation in isolated rat-liver nuclei by promoting the redox activity of endogenous copper ions. Biochem. J. 133: 163169

Burton KA (1956) A study of the conditions and mechanism of the diphenylamine reaction for the colorimetric estimation of deoxyribonucleic acid. Biochem. J. 62 : 315-323

Clawson GA, Norbeck LL, Hatem CL, Rhodes C, Amiri P, McKerrow JH, Patierno SR and Fiskum $\mathrm{G}$ (1992) $\mathrm{Ca}^{2+}$-regulated serine protease associated with the nuclear scaffold. Cell Growth Differ. 3: 827-838

Clawson GA, Norbeck LL, Wise JP and Patierno SR (1993) An inhibitor of nuclear scaffold protease blocks chemical transformation of fibroblasts. Cell Growth Differ. 4: 589-594

Cohen JJ and Duke RC (1984) Glucocorticoid activation of a calcium-dependent endonuclease in thymocyte nuclei leads to cell death. J. Immunol. 132: 38-42

Crompton T, Peitsch MC, MacDonald HR and Tschopp J (1992) Propidium iodide staining correlates with the extent of DNA degradation in isolated nuclei. Biochem. Biophys. Res. Commun. 183: 532-537

D'Murcia G and DéMurcia JM (1994) Poly(ADP-ribose)polymerase: a molecular nick-sensor. Trends Biochem. Sci. 19: 172-176

Earnshaw WC (1995) Apoptosis: lessons from in vitro systems. Trends Cell Biol. 5: 217-220

Faucheu C, Diu A, Chan AW, Blanchet AM, Miossec C, Herve F, Collard-Dutilleul V, Gu Y, Aldape RA, Lippke JA, Rocher C, Su MS-S, Livingson DJ, Hercend T and Lalanne J-L (1995) A novel human protease similar to the interleukin-1 beta converting enzyme induces apoptosis in transfected cells. EMBO J 14: 19141922
Fernandes-Alnemri T, Litwack G and Alnemri ES (1994) CPP32, a novel human apoptotic protein with homology to Caenorhabditis elegans cell death protein Ced-3 and mammalian interleukin-1 $\beta$-converting enzyme. J. Biol. Chem. 269: 30761-30764

Fernandes-Alnemri T, Litwack G and Alnemri ES (1995a) Mch2, a new member of the apoptotic Ced-3/Ice Cysteine protease gene family. Cancer Res. 55:2737-2742

Fernandes-Alnemri T, Takahashi A, Armstrong R, Krebs J, Fritz L, Tomaselli KJ, Wang L, Yu Z, Croce CM, Salveson G, Earnshaw WC, Litwack G and Alnemri ES (1995b) Mch3, a novel human apoptotic cysteine protease highly related to CPP32. Cancer Res. 55: 6045-6052

Gerace L and Blobel G (1980) The nuclear envelop lamina is reversibly depolymerized during mitosis. Cell 19: 277-287

Gu Y, Sarnecki C, Aldape RA, Livingston DJ and Su MS (1995) Cleavage of poly(ADP-ribose) polymerase by interleukin-1 beta converting enzyme and its homologs TX and Nedd-2. J. Biol. Chem. 270: 18715-18718

Jiang S, Chow SC, McCabe MJ JR and Orrenius S (1995) Lack of Ca ${ }^{2+}$ involvement in thymocyte apoptosis induced by chelation of intracellular $\mathrm{Zn}^{2+}$. Lab. Invest. 73 : 111-117

Kamens J, Allen H, Banach D, Bump N, Hachett M, Johanston CG, Li P, Mankovich JA, Terranova M and Chayur T (1995) Identification and characterization of ICH2 , a novel member of the interleukin- 1 beta-converting enzyme family of cysteine protease. J. Biol Chem. 270: 15250-15260

Kaufmann SH, Desnoyers S, Ottaviano Y, Davidson NE, Poirier GG (1993) Specific proteolytic cleavage of poly(ADP-ribose) polymerase: an early marker of chemotherapy-induced apoptosis. Cancer Res. 53: 3976-3985

Kumar S (1995) ICE-like proteases in apoptosis. Trends Biochem. Sci. 20: 198-202

Kumar S, Kinoshita M, Noda M, Copeland NG and Jenkins NA (1994) Induction of apoptosis by the mouse Nedd2 gene, which encodes a protein similar to the product of the Caenorhabditis elegans cell death gene ced-3and the mammalian IL-1 $\beta$-converting enzyme. Genes Develop. 8: 1613-1626

Lazebnik YA, Cole S, Cooke CA, Nelson WG and Earnshaw WC (1993) Nuclear events of apoptosis in vitro in cell-free mitotic extract: a model system for analysis of the active phase of apoptosis. J. Cell Biol. 123: 7-22

Lazebnik YA, Kaufmann SH, Desnoyers S, Poirier GG and Earnshaw WC (1994) Cleavage of poly(ADP-ribose) polymerase by a proteinase with properties like ICE. Nature 371: 346-347

Lazebnik YA, Takahashi A, Moir RD, Goldman RD, Poirier GG, Kaufmann SH and Earnshaw WC (1995) Studies of the lamin proteinase reveal multiple parallel biochemical pathways during apoptotic execution. Proc. Natl. Acad. Sci. USA 92: 9042-9046

Lindahl T, Satoh MS, Poirier GG and Klungland A (1995) Post-translational modification of poly(ADP-ribose) polymerase induced by DNA strand breaks. Trends Biochem. Sci. 20: 405-411

Martin SJ and Green DR (1995) Protease activation during apoptosis: death by a thousand cut? Cell 82: 349-352

Martin SJ, Newmeyer DD, Mathias S, Farschon DM, Wang H-G, Reed JC, Kolesnick RN and Green DR (1995) Cell-free reconstitution of Fas-, UV radiation- and ceramide-induced apoptosis. EMBO J 14: 5191-5200

McCabe MJ Jr, Jiang S and Orrenius S (1993) Chelation of intracellular zinc triggers apoptosis in mature thymocytes. Lab. Invest. 69: 101-110

McConkey DJ and Orrenius S (1994) Signal transduction pathway to apoptosis. Trends Cell Biol. 4: 370-375

Mirura M, Zhu H, Rotello R, Hartwieg EA and Yuan J (1993) Induction of apoptosis in fibroblasts by IL- 1 beta-converting enzyme, a mammalian homolog of the $C$. elegance cell death gene ced-3. Cell 75: 653-660

Neamati N, Fernandez A, Wright S, Kiefer J and McConkey DJ (1995) Degradation of lamin B1 precedes oligonucleosomal DNA fragmentation in apoptotic thymocytes and isolated thymocyte nuclei. J Immunol. 154: 3788-3795

Nicholson DW, Ali A, Thornberry A, Vaillancourt JP, Ding CK, Gallant M, Gareau Y, Griffin PR, Labelle M, Lazabnik YA, Munday NA, Raju SM, Smulson ME, Yamin TT, Yu VL and Miller DS (1995) Identification and inhibition of the ICE/CED-3 protease necessary for mammalian apoptosis. Nature 376: 37-43

Oberhammer FA, Hochegger K, Fröschl G, Tiefenbacher R and Pavelka, M (1994) Chromatin condensation during apoptosis is accompanied by degradation of lamin A+B, withoutenhanced activation of cdc2 kinase. J. Cell Biol. 126:827-837

Schlegel J, Peters I, Orrenius S, Miller DK, Thornberry NA, Yamin T-T and Nicholson DW (1996) CPP32/Apopain is a key ICE-like protease involved in Fas-mediated apoptosis. J. Biol. Chem. 271: 1841-1844 
Sunderman FW JR (1995) The influence of zinc on apoptosis. Ann. Cli. Lab. Sci. 25 134-142

Tewari M, Beidler DR and Dixit VM (1995a) CrmA-inhibitable cleavage of the $70 \mathrm{kDa}$ protein component of the U1 small nuclear ribonucleoprotein during Fas- and tumor necrosis factor-induced apoptosis. J. Biol. Chem. 270: 18738-18741

Tewari M, Quan LT, O'Rourke K, Desnoyers S, Zeng Z, Beidler DR, Poirier GG, Salvesen GS, and Dixit VM (1995b) Yama/CPP32 $\beta$, a mammalian homolog of CED-3, is a CrmA-inhibitable protease that cleaves the death substrate poly(ADP-ribose) polymerase. Cell 81: 801-809

Wang L, Miura M, Bergeron L, Zhu H and Yuan J (1994) Ich-1, an Ice/ced-3-related gene, encodes both positive and negative regulators of programmed cell death. Cell 78: 739-750
Wang X, Pai JT, Wiedenfeld EA, Medina JC, Slaughter CA, Goldstein JL and Brown MS (1995) Purification of an interleukin-1 beta converting enzyme-related cysteine protease that cleaves sterol regulatory element-binding proteins between the leucine zipper and transmembrane domains. J. Biol. Chem. 270: 18044-18050

Wyllie AH, Kerr JFR and Currie AR (1980) Cell death: the significance of apoptosis. Int. Rev. Cytol. 68: 251-306

Yuan J, Shaham S, Ledoux S, Ellis HM and Horvits HR (1993) The C. elegans cell death gene ced-3 encodes a protein similar to mammalian interleukin-1 betaconverting enzyme. Cell 75: 641-652

Zhivotovsky B, Gahm A, Ankarcrona M, Nicotera P and Orrenius S (1995) Multiple proteases are involved in thymocyte apoptosis. Exp. Cell Res. 221: 404-412 